нового типу мислення вчителя - так званого, проектного, про розвиток його проективних здібностей, активне залучення до проектної діяльності.

Модульна система навчання, що спрямовує сучасну освіту на особистість, вимагає враховувати певні аспекти, зокрема: зміну головної мети технологічної освіти; зважати на особливу роль міжпредметних зв'язків у технологічній освіті; особистісну орієнтацію майбутнього вчителя технологій на неперервну освіту, що передбачає постійне оновлення технологічних знань та вмінь.

1. Балыхин Г. А. Управление развитием образования: организационноэкономический аспект / Григорий Артемович Балыхин. - М. : Экономика, 2003. 427 c. 2. Банько Н. А. Формирование профессионально-педагогической компетентности как компонента профессиональной подготовки менеджеров: [монография] / Н. А. Банько. - Волгоград : ВолгГТУ. - 2004. - 75 с. 3. Борисенко Н. Професійна підготовка майбутніх учителів технологій в умовах сучасного освітнього простору / Надія Борисенко // Проблеми підготовки сучасного вчителя: збірник наукових праць Уманського державного педагогічного університету імені Павла Тичини / [ред. кол. : Побірченко Н. С. (гол. ред.) та ін.]. - Умань : ПП Жовтий О. О., 2011. - Випуск 4. - Частина 2. - С. 295-301. 4. Иголкина М. И. Педагогические условия обеспечения компетентностного похода в подготовке педагога : дис. ... канд. пед. наук/ Мария Ивановна Иголкина / 13.00.01 «Общая педагогика, история педагогики образования».- M., 2008 [Электронный ресурс].- Режим доступа: http://nauka-pedagogika.com\pedagogika-13-00-01/disertaciya-pedagogicheskie-uslo

5. Тименко В. П. Початкова дизайн-освіта: теорія i практика формування конструктивних умінь особистості : [монографія] / Володимир Петрович Тименко. К. : Педагогічна думка, 2010. - 380 с. 6. Хазова Л. В. Концептуальные основы и опыт модернизации образования: гуманистические и гуманитарные аспекты / Л. В. Хазова. - Красноярск: Изд-во КГТУ, 1997. - 184 с. 7. Чернышева Е. И. Форимирование профессиональной компетентности будущих педагогов в развитии технологического мышления: дис. ... канд. пед. наук : 13.00.08, 13.00.01 / Чернышева Елена Ивановна. - Воронеж, 2005. - 182 с.

УДК 378:[37.011.3-051]:62/64

Світлана Кучер

\title{
ОЦІНЮВАННЯ ПРОЕКТНОЇ ДІЯЛЬНОСТІ МАЙБУТНІХ УЧИТЕЛІВ НА ОСНОВІ ВИКОРИСТАННЯ ІНФОРМАЦЙНО-КОМУНІКАЦЙНИХ ТЕХНОЛОГІЙ (ЗА ПРОГРАМОЮ INTЕL «НАВЧАННЯ ДЛЯ МАЙБУТНЬОГО»)
}

Кучер С. Л. Оцінювання проектної діяльності майбутніх учителів на основі використання інформаційно-комунікаційних технологій (за програмою Intel «Навчання для майбутнього»).

У статті розглядаються можливості впровадження програми Intel «Навчання для майбутнього в Україні» у процес оцінювання результатів творчого проектування майбутніх учителів технологій.

Ключові слова: інформаційно-комунікаційні технології (ІКТ), оцінювання, технологічна освіта, навчальні проекти, освітні програми Intel.

Кучер С. Л. Оценка проектной деятельности будущих учителей на основе использования информационно-коммуникационных технологий (по программе Intel «Обучение для будущего»). 
В статье рассматриваются возможности использования программы Intel «Обучение для будущего в Украине» в процессе оценивания результатов творческого проектирования будущих учителей технологий.

Ключевые слова: информационно-коммуникационные технологии (ИКТ), оценивание, технологическое образование, учебные проекты, образовательные программы Intel.

Kucher S. L. Evaluation of future teachers' project activity through the use of information and communication technologies (Intel Program «Education for the Future»).

The article examines possibilities of applying Intel Program «Education for the Future in Ukraine» in evaluating results as for creative designing of future teachers of technologies.

Key words: information and communication technologies (ICT), evaluations, technological education, educational projects, Intel educational programs.

Реалії сучасної освіти засвідчують недостатню узгодженість між підготовкою фахівців та вимогами до їх знань під час працевлаштування. Високі технології в усіх галузях професійної діяльності людей відіграють важливу роль і $\epsilon$ підгрунтям економічного зростання. Близько 80 \% робочих місць вимагають від фахівця знання комп'ютерної техніки і застосування різних її можливостей.

Майбутній учитель уже під час навчання у вищому навчальному закладі має ознайомитися із можливостями застосування інформаційно-комунікаційних технологій у шкільній практиці. Можливості для цього надає програма Intel «Навчання для майбутнього»- для працюючих та майбутніх учителів, що впроваджується в Україні протягом останніх років. Навчання ефективному застосуванню IКТ та новітніх педагогічних технологій у навчально-виховному процесі має на меті підготовку учнів до «економіки знань» та надання їм навичок XXI сторіччя.

Інформаційно-комунікаційні технології є основою для трансформації навчання. Можливості сучасних дистанційних освітніх технологій розглядаються у працях таких науковців, як: В. Биков, А. Бітченко, О. Воронкін, М. Жалдак, В. Кухаренко, Л. Лещенко, В. Олійник, С. Семеріков, П. Таланчук, В. Толочко та ін. Проте ще недостатньо розкрито питання підготовки майбутніх учителів технології до використання ІКТ в організації проектної діяльності учнів у школі. Як базу для такої підготовки можна використовувати освітні ініціативи Intel, що діють у нашій державі.

Компанія Intel протягом 15 років в Україні ініціює та підтримує освітні процеси, пов'язані з упровадженням комп'ютерних технологій у процес навчання в усьому світі. В Україні з 2003 року діють такі програми:

1. Програма Intel «Навчання для майбутнього» («Intel Teach»)

2. Програма Intel «Шлях до успіху» («Intel Learn»)

3. Програма Intel ISEF (International Science and Engineering Fair)

Усі освітні проекти компанії спрямовані на розвиток талантів, які і будуть створювати нові технології й інновації. Оскільки освіта повинна культивувати інноваційне мислення, необхідно надати, окрім теоретичної бази, ще й практичні навички, що є можливим тільки за допомогою створення нових стандартів, програм, i, головне, - середовища для отримання якісно нової, персоналізованої освіти [1].

Метою статmi є розгляд можливостей використання основного курсу Intel «Навчання для майбутнього» як бази в організації оцінювання навчальних проектів, що виконуються майбутніми вчителями технологій під час навчання у ВНЗ.

Метод проектів останніми роками став провідним у викладанні трудового 
навчання в Україні. Саме тому виконання проектів за системою «Інтел» надає можливостей учителю трудового навчання узгоджувати глибоке всебічне теоретичне вивчення тем із подальшим утіленням у виробі, минаючи традиційні реферативні виклади матеріалу. Пасивна роль учня як слухача та виконавця відходить у минуле, натомість змінюючись активною творчою позицією учнів як дослідників та експериментаторів, а подекуди й експертів. Програма є каталізатором реформування освітнього простору України, оновлення змісту й методів ІКТ освіти, упровадження інтерактивних форм підготовки й перепідготовки педагогічних кадрів, покращення стану інформатизації освіти.

Самі по собі інформаційно-комунікаційні технології, які вчитель може використовувати у навчально-виховному процесі, знайомі учням середньої та старшої школи, оскільки йдеться про електронну пошту, пошукові системи всесвітньої мережі, сайти та електронні щоденники. Водночас у нашій країні ці засоби комунікацій нечасто системно використовуються в освіті. Натомість в економічно розвинених країнах застосування ІКТ на всіх рівнях освіти підтримується державними установами. Подібні стратегії модернізації освіти становлять цінний досвід для України.

Так, у Великобританії чинними є урядові програми, які можна узагальнити терміном «ІКТ в освіті», що трактується як «сукупність методів та прийомів систематичного і цілеспрямованого застосування IКТ для підвищення ефективності навчального процесу, що передбачає досягнення педагогічних цілей, реалізацію принципів навчання задля розвитку ІКТ-компетентності особистості, яка створює, отримує, зберігає, накопичує, обробляє, поширює та передає інформацію, а також спілкується у мережі» [3, с. 22].

Для організації виконання проекту з певної теми шкільної програми учитель має підготувати навчально-методичний комплекс, який полягає в розробленні плану вивчення теми, створенні сайту вчителя (де будуть представлені презентації основних питань для учнів, опитувальника для учнів, добору вправ або завдань у комп'ютерному форматі, якими б могли скористатися учні під час самостійного вивчення матеріалу, розроблення критеріїв оцінювання). Весь цей матеріал формує індивідуальне портфоліо вчителя.

Вимоги до навчального матеріалу, вивчення якого базується на комп'ютерній технології, підвищуються порівняно з традиційною. В. Красильнікова підкреслює, що корисність, відповідність рівню підготовленості учня, поступове нарощення рівня складності, напруження в роботі є умовами формування правильно розробленого методичного забезпечення. «Навчальний матеріал повинен мати не лише текст, але бажано повний набір усього дидактичного матеріалу (схеми, рисунки, таблиці, графіки, вправи й пояснення до їх виконання, питання поточного контролю та правильні відповіді), вихід на довідкову літературу, інші середовища навчання (використання розподілених інформаційно-навчальних ресурсів)» [5, с. 145-146].

Проте головним у цій підготовчій роботі $є$ не тільки створення, але й надання доступу учням до перерахованих методичних матеріалів, яке здійснюється через електронну пошту gmail.com завдяки особливим можливостям Google. Базові вміння для організації та керівництва проектами на основі IКТ передбачають володіння педагогом та учнями навичками користування персональним комп'ютером, навички роботи в мережі Intrenet, досвід користування програмами Microsoft Word, Publisher, Excel, PowerPoint.

На початку виконання проекту з певної теми (в цілому розрахованої приблизно на 2-5 тижнів) педагог залучає учнів до створення таблиці «знаю - хочу дізнатися - 
дізнаюся», де спільно визначається рівень раніше набутих знань та ставиться мета вивчення теми. Далі викладач пропонує учням розділитися на групи і визначити свій «експертний профіль» (з позицій якого фахівця будуть розглядатися питання визначеної проблеми). Кожна група експертів розглядає тему проекту зі своєї позиції, представляючи результат у вигляді трьох груп питань (змістові, тематичні та ключові). Ці питання становлять основу плану розв'язання навчальної проблеми. Саме ключові питання відображають мету навчальної діяльності, пов'язану 3 формуванням навичок XXI століття, зокрема творчість і інноваційність, критичне мислення i вміння розв'язувати проблеми, комунікативні навички та навички співробітництва, вміння працювати 3 інформацією, медіа та комп'ютерні навички, інформаційна грамотність (ІКТ-грамотність), а також життєві та кар'єрні навички (гнучкість та пристосовуваність, ініціатива та самоспрямованість, соціальні навички та навички, пов'язані зі співіснуванням різних культур, продуктивність та вміння 3'ясовувати та враховувати кількісні показники, лідерство та відповідальність) [2].

Схематично послідовність і зміст виконання проектів за допомогою IКТ, на нашу думку, має таку етапність (рис. 1).

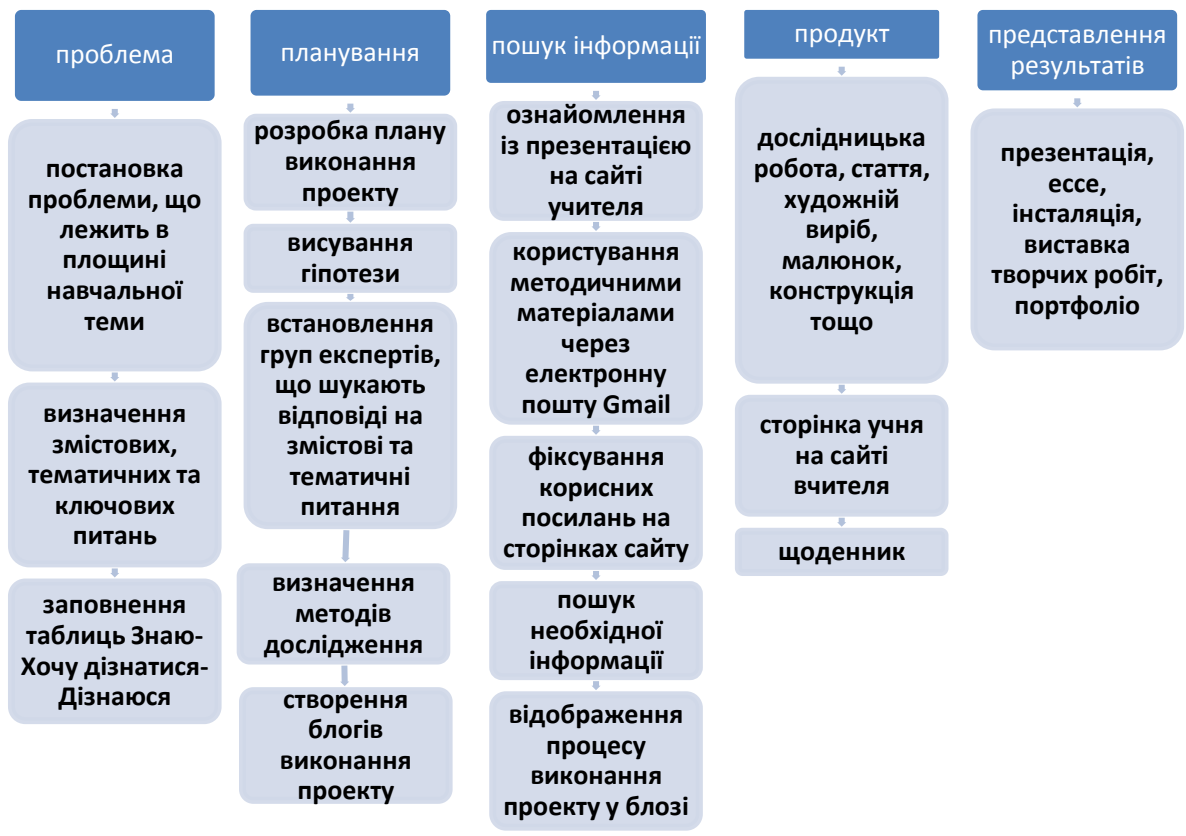

Рис. 1. Схема послідовності виконання проектів за допомогою ІКТ

Процес виконання учнями проекту здійснюється без керівництва вчителя, але супроводжується його спостереженням, консультаціями та контролем, відповідно й оцінюванням. Завдяки комп'ютерному забезпеченню процесу фіксуються індивідуальні проміжні результати виконання проекту, які педагог може відслідковувати. Для себе викладач створює графік оцінювання [1], де вказано методи та інструменти оцінювання, що допомагають визначити попередні знання, уміння, навички та ставлення учнів, їх ставлення та можливі неправильні уявлення щодо теми 
на початку проекту; визначити навчальні потреби учнів, а також відслідковувати їх прогрес у навчанні, перевірити розуміння, а також заохотити до пізнання особливостей власного мислення, самокерування в навчанні та співпраці впродовж роботи над проектом; виявити рівень розуміння вивченого, навички учнів, які вони отримали в результаті роботи над проектом, а також заохотити учнів до подальшого пізнання своїх особливостей мислення, визначити подальші навчальні потреби учнів та спонукати їх до подальшого навчання.

Задля залучення учнів до процесу оцінювання вчитель має забезпечити їх таким: чіткими критеріями оцінювання до початку виконання проектів і творчих роботи учнів; моделями та інструкціями для високоякісної роботи; можливостями для здійснення моніторингу - відслідковування ходу власного просування в навчанні; засобами надання конструктивного зворотного зв'язку іншим учням та можливостями отримання оціночних даних від інших учнів для того, щоб покращити власну виконану роботу і діяльність; надати достатньо часу для представлення результатів та поліпшення процесів і продуктів; підтримкою для формування учнями власних нових завдань для їх майбутнього навчання.

Важливе значення для майбутнього педагога має самооцінка, яка паралельно 3 оцінкою викладача фіксується в електронній таблиці оцінювання результатів виконання проектів, доступ до якої мають усі суб'єкти навчального процесу. У такий спосіб демократичний принцип оцінювання реалізується найбільш вдало.

Оскільки використовуються й індивідуальна, і групова форми роботи, педагог повинен методично грамотно побудувати оцінювальну діяльність. Обов'язковою умовою застосування ІКТ під час розроблення навчальних проектів $\epsilon$ індивідуальний підхід і можливість кооперації учнів між собою та з учителем у процесі навчання.

Оцінювання навчальної діяльності студентів, які виконують роботу малими групами, науковці Н. Коренькова та О. Кореньков пропонують здійснювати на основі технології колективної мисленнєвої діяльності. Отримавши завдання, студенти розробляють власні методи визначення певних показників (наприклад, встановлення основного принципу побудови гармонії у візерунку). Далі завдання виконується у три етапи: індивідуальна робота, обговорення в мікрогрупі, представлення колективного рішення. Потім викладач пропонує кожній групі ознайомитися 3 лабораторним обладнанням та об'єктом дослідження для виконання практичної роботи, подати схему iї виконання, порівнявши із запропонованими раніше методами визначення. Взаємооцінка студентами навчальної діяльності має місце після презентації всіх колективних проектів та рішень. Студенти кожної мікрогрупи оцінюють роботу своїх колег за такими критеріями: послідовність та логічність представлення проекту; адекватність форми представлення змісту матеріалу; уміння виокремити та відобразити головне; творчий підхід до пошуку та представлення рішення [4, с. 133134].

На особливу увагу заслуговує методичне забезпечення для оцінювання, запропоноване програмою «Інтел», адже коли оцінювання визначає процес навчання, учні більше знають, стають більш упевненими, розширюється світогляд. Оцінювання роботи учнів відбувається протягом усієї роботи над проектом. Учитель планує його так, щоб використовувати різноманітні стратегії та засоби оцінювання; вести оцінювання упродовж навчального циклу; надавати можливість кількісно оцінювати важливі навчальні цілі для теми; залучати учнів до процесу оцінювання.

Оцінювання проектів, орієнтоване на розвиток навичок XXI століття, допомагає вчителям вибудовувати певну стратегію навчального процесу, у якому учні глибше розуміють вивчене, думають на більш високому рівні і стають цілеспрямованими в 
навчанні. Користуючись можливостями системи «Google», учитель і учні можуть відчути переваги різних видів оцінювання (само- i взаємооцінювання). Завдяки технології «Інтел» педагог може створити засоби оцінювання власноруч або використовувати напрацювання своїх колег. У такий спосіб учитель набуває ролі фасилітатора, консультанта, який спостерігає, спрямовує, підказує, керуючи навчальною діяльністю учнів за принципами гуманістичної педагогіки.

\section{Література}

1. Partnership for 21st Century Skills: [Електронний ресурс].- Режим доступу: www.21stcenturyskills.org 2. Зубченко О. С. Інформаційно-комунікаційні технології у педагогічній теорії та практиці Великобританії/ О.С. Зубченко // Сучасні інформаційні технології та інноваційні методики навчання у підготовці фахівців: методологія, досвід, проблеми: зб. наук. праць. - Київ-Вінниця : Планер, 2012.Вип. 33. - С. 19-23. 3. Коренькова Н. В. Способы оценивания учебной деятельности студентов / Н. В. Коренькова, А. Э. Кореньков // Оценивание: образовательные возможности: сб. науч.-метод. статей /под. общ ред. М. А. Гусаковского. - Мн. : БГУ, 2006. - Вып. 4. - С. 133-138. 4. Красильникова В. А. Теория и технологии компьютерного обучения и тестирования: [монография] / В. А. Красильникова. - М. : Дом педагогики, ИПК ГОУ ОГУ, 2009. - 339 с.

УДК $378.141: 64$

Олена Лихолат

\section{КОМПОНЕНТИ І ЧИННИКИ ФОРМУВАННЯ ЗМІСТУ НАВЧАЛЬНОГО КУРСУ «ДОМОЗНАВСТВО» В СИСТЕМІ ПІДГОТОВКИ ВЧИТЕЛЯ ТЕХНОЛОГІЙ}

Лихолат О. В. Компоненти і чинники формування змісту навчального курсу «Домознавство» в системі підготовки вчителя технологій.

У статті розкриваються теоретико-практичні аспекти формування змісту навчальної дисципліни «Домознавство» в системі підготовки вчителя технологій за спеціалізацією «Основи домашнього господарювання» Автор пропонує підходи до відбору складників змісту, обгрунтовує доцільність запровадження окремих навчальних модулів у змісті програми.

Ключові слова: технологічна освіта, зміст освіти, чинники, компоненти змісту освіти, принципи формування змісту освіти, навчальний курс «Домознавство».

Лихолат Е. В. Компоненты и факторы формирования содержания учебного курса «Домоводство» в системе подготовки учителя технологий.

Статья раскрывает теоретико-практические аспекты процесса формирования содержания учебной дисциплины «Домоводство» в системе подготовки учителя технологий по специализации «Основы домашнего хозяйствования». Автор предлагает подходы к отбору составных частей содержания, обосновывает целесообразность ввода отдельных учебных модулей в содержание программы.

Ключевые слова: технологическое образование, содержание образования, факторы, компоненты содержания образования, принципы формирования содержания образования, учебный курс «Домоводство».

Lykholat H. V. Components and factors of forming the content of the educational course "Housekeeping" in the system of training a teacher of technologies.

The article exposes theoretical and practical aspects of the process of forming the 